\title{
Identification of novel surfactin derivatives from NRPS modification of Bacillus subtilis and its antifungal activity against Fusarium moniliforme
}

\author{
Jian Jiang, Ling Gao, Xiaomei Bie*, Zhaoxin Lu, Hongxia Liu, Chong Zhang, Fengxia Lu and Haizhen Zhao
}

\begin{abstract}
Background: Bacillus subtilis strain PB2-L1 produces the lipopeptide surfactin, a highly potent biosurfactant synthesized by a large multimodular nonribosomal peptide synthetase (NRPS). In the present study, the modules SrfA-A-Leu, SrfA-B-Asp, and SrfA-B-Leu from surfactin NRPS in B. subtilis BP2-L1 were successfully knocked-out using a temperature-sensitive plasmid, pKS2-mediated-based, homologous, recombination method.

Results: Three novel surfactin products were produced, individually lacking amino acid Leu-3, Asp-5, or Leu-6. These surfactins were detected, isolated, and characterized by HPLC and LC-FTICR-MS/MS. In comparison with native surfactin, $\left[\Delta \mathrm{Leu}^{3}\right]$ surfactin and $\left[\Delta \mathrm{Leu}^{6}\right]$ surfactin showed evidence of reduced toxicity, while $\left[\Delta \mathrm{Asp}^{5}\right]$ surfactin showed stronger inhibition than native surfactin against $B$. pumilus and Micrococcus luteus. These results showed that the minimum inhibitory concentration of $\left[\Delta\right.$ Leu $\left.{ }^{6}\right]$ surfactin for Fusarium moniliforme was $50 \mu \mathrm{g} / \mathrm{mL}$, such that $\left[\Delta L \mathrm{Lu}^{6}\right]$ surfactin could lead to mycelium projection, cell damage, and leakage of nucleic acids and protein. These factors all contributed to stimulating apoptosis in F. moniliforme.
\end{abstract}

Conclusions: The present results revealed that $\left[\Delta \mathrm{Leu}^{6}\right]$ surfactin showed a significant antifungal activity against $F$. moniliforme and might successfully be employed to control fungal food contamination and improve food safety.

Keywords: Surfactin, NRPS, Module deletion, Fusarium moniliforme

\section{Background}

Fusarium moniliforme mainly contaminates maize, sorghum, wheat, cotton, beans, tomatoes, peanuts, bananas, beans, peppers, and some feeds. Among these materials, maize is the most prone to fungal infection, accounting for almost $90 \%$ of all types of food pollution $[1,2]$. As one of the most common fungi, Fusarium mycotoxin researchers are currently most concerned about F. moniliforme. Currently, surfactins are used for their antibacterial, antiviral, anti-tumor, and hemolytic activities [3-6]. However, surfactins do not only inhibit filamentous fungi, but C15 surfactin has a synergistic inhibition effect on filamentous fungi. The lipopeptide surfactin family has a ring

\footnotetext{
* Correspondence: bxm43@njau.edu.cn

College of Food Science and Technology, Nanjing Agricultural University, Key Laboratory of Food Processing and Quality Control, Ministry of Agriculture of China, 1 Weigang, Nanjing 210095, P.R. China
}

structure peptide chain and possesses a $\beta$-hydroxy fatty acid chain (typically $\mathrm{C}_{13}-\mathrm{C}_{16}$ ) containing seven amino acids formed by crosslinking [7]. There has been great interest in these compounds because of their potential biological activities as well as economic value. Lipopeptides are often composed of seven or fewer modules composed of amino acids components. Surfactin consists of a Glu-Leu-Leu-ValAsp-Leu-Leu peptide, synthesized by large multifunctional nonribosomal peptide synthetases (NRPSs) via the multiple thiotemplate mechanism $[8,9]$. The composite module can be modified by epimerization, methylation, acylation, or cyclization. The final lipopeptide products can have linear, cyclic, or branched peptide backbones [10].

In this study, a procedure is described that allows for efficient and relatively fast inactivation of a Bacillus subtilis gene to create new, biotechnologically interesting products. The approach is the same as developed has 
been for some other Gram-positive strains [11, 12] and uses a high temperature-sensitive, shuttle plasmid based on the pKS2 replication origin. Plasmid pKS2 replicates at $30{ }^{\circ} \mathrm{C}$, but $37^{\circ} \mathrm{C}$ is nonpermissive for plasmid replication. This method is different from the traditional twostep knockout method [13] and can quickly knock out a module with precision. In contrast, the two-step method usually cannot avoid the impact of an exogenous antibiotic resistance gene.

B. subtilis strain BP2-L1 produces surfactin following the integration of genes $s f p$ and $\operatorname{deg} Q$ into the B. subtilis BP2 chromosome [14]. For knock out of the modules SrfAA-Leu, SrfA-B-Asp, and SrfA-B-Leu of surfactin NRPSs in $B$. subtilis $\mathrm{BP} 2-\mathrm{L} 1$, the $\mathrm{pKS} 2$-mediated, temperaturesensitive, homologous recombination method was used. The structures of the resulting novel surfactins were identified and isolated to develop new antibacterial lipopeptides with stronger antimicrobial activity and more beneficial characteristics.

\section{Methods}

\section{Strains, plasmids, and media}

Strains and plasmids used in this study are listed in Table 1. B. subtilis strain PB2-L1, a derivative of B. subtilis 168 (trpC2) developed to produce surfactin [14], was used as the source of surfactin synthetase genes and for engineering surfactin synthetase. B. subtilis PB2 was a model strain of Bacillus subtilis from Chester Price' lab of UCDavis. pMD19T-simple vector was a commercial carrier and pKS2 vector was temperature sensitive vector for gene deletion. Escherichia coli DH5 $\alpha$ was used for cloning procedures and propagation of plasmids; pKS2-based vectors can be replicated at $30{ }^{\circ} \mathrm{C}$ in E. coli. Before transforming $B$. subtilis, plasmids were purified from E. coli strain JM110 to obtain the unmethylated forms. Bacterial cells were cultivated in Luria broth (LB, $5 \mathrm{~g}$ yeast extract/L, $10 \mathrm{~g}$ peptone/L, and $10 \mathrm{~g} \mathrm{NaCl} / \mathrm{L}$ ) or in Landy medium [15] supplemented with $0.1 \%$ yeast extract and $2 \mathrm{mg} / \mathrm{L}$ phenylalanine [16], at temperatures of 28 or $37^{\circ} \mathrm{C}$. Ampicillin was added to $100 \mu \mathrm{g} / \mathrm{mL}$.

\section{Plasmid construction}

The 0.59-kb fragment of the upstream SrfA-A-Leu module and 0.51-kb fragment of the downstream SrfA-ALeu module were amplified using the primer pairs, 5' srfA-A- $\Delta$ Leu-up-F/3' srfA-A- $\Delta$ Leu-SOE-up-R and $5^{\prime}$ srfA-A- $\Delta$ Leu-SOE-down-F/3'srfA-A- $\Delta$ Leu-down-R, respectively. Because of the 15 bp overlapping fragment in 3 'srfA-A- $\triangle$ Leu-SOE-up-R and 5'srfA-A- $\Delta$ Leu-SOEdown-F, these two fragments were used as templates for overlapping PCR with the primers 5'srfA-A- $\Delta$ Leu-up-F and 3'srfA-A- $\Delta$ Leu-down-R [17]. The 1107 bp upstream and downstream fragments of SrfA-A-Leu module were modified with KpnI and XhoI and ligated with
Table 1 Bacterial strains and plasmids used in this study

\begin{tabular}{|c|c|c|}
\hline Strain/plasmid & Relevant genotype/description & Reference \\
\hline \multicolumn{3}{|l|}{ E. coli } \\
\hline $\mathrm{DH} 5 \mathrm{a}$ & recA1, endA1, lacZDM15 & $\begin{array}{l}\text { New England } \\
\text { Biolabs }\end{array}$ \\
\hline JM110 & 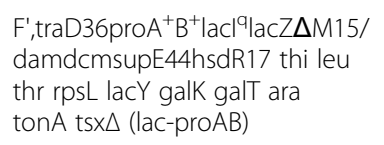 & Transgen Biolabs \\
\hline \multicolumn{3}{|l|}{ B. subtilis } \\
\hline B. subtilis PB2 & B. subtilis $168 \operatorname{trpC2}$ & $\begin{array}{l}\text { Chester Price' lab } \\
\text { (UCDavis, USA) }\end{array}$ \\
\hline $\begin{array}{l}\text { B. subtilis PB2- } \\
\text { L1 }\end{array}$ & $\begin{array}{l}\text { Derivative of } B \text {. subtilis } \\
\text { PB2 Produces surfactin }\end{array}$ & Our labs \\
\hline B. subtilis LS1 & $\begin{array}{l}\text { Lacking the third D-leucine } \\
\text { module from } B \text {. subtilis PB2-L1 }\end{array}$ & This work \\
\hline B. subtilis LS6 & $\begin{array}{l}\text { Lacking the fifth L-aspartate } \\
\text { module from } B \text {. subtilis PB2-L1 }\end{array}$ & This work \\
\hline B. subtilis LS9 & $\begin{array}{l}\text { Lacking the sixth D-leucine } \\
\text { module from B. subtilis PB2-L1 }\end{array}$ & This work \\
\hline \multicolumn{3}{|l|}{ Plasmids } \\
\hline pMD19T-simple & TA cloning vector; $A m p^{R}$ & TAKARA \\
\hline pKS2 & $\begin{array}{l}\text { Thermosensitive vector; } \\
\operatorname{Kan}^{R}, \operatorname{Erm}^{R}\end{array}$ & Our labs \\
\hline $\begin{array}{l}\text { pKS2-srfA- } \\
\text { C- } \triangle \text { Leu }\end{array}$ & $\begin{array}{l}\text { Third D-leucine module } \\
\text { knock-out vector; Kan }{ }^{R}, \operatorname{Erm}^{R}\end{array}$ & This work \\
\hline $\begin{array}{l}\text { pKS2-srfA- } \\
\text { B- } \triangle \text { Asp }\end{array}$ & $\begin{array}{l}\text { Fifth L-aspartate module } \\
\text { knock-out vector; } \operatorname{Kan}^{R} \text {, } \text { Erm }^{R}\end{array}$ & This work \\
\hline $\begin{array}{l}\text { pKS2-srfA- } \\
\text { B- } \triangle \text { Leu }\end{array}$ & $\begin{array}{l}\text { Sixth D-leucine module } \\
\text { knock-out vector; } \operatorname{Kan}^{R}, \mathrm{Erm}^{R}\end{array}$ & This work \\
\hline
\end{tabular}

similarly treated E. coli and B. subtilis shuttle vector pKS2 to yield pKS2-srfA-C- $\Delta$ Leu (Table 1 ). The construction of pKS2-srfA-B- $\triangle \mathrm{Asp}$ and pKS2-srfA-B$\Delta$ Leu used similar methods. The Accession Numbers of all nucleic acid primers is NC_000964.3 from NCBI database.

\section{B. subtilis strain construction}

Traditional chemical transformation was used in B. subtilis strain construction. The genotypes of new transformants were identified via PCR. B. subtilis PB2-L1 transformed with the temperature-sensitive vectors pKS2-srfA-C- $\Delta$ Leu, pKS2-srfA-B- $\triangle$ Asp, and pKS2-srfAB- $\Delta$ Leu. The host strain E. coli JM110 can modify the shuttle vector pKS2 by demethylation and, by modifying demethylation, the rate of $B$. subtilis transformation can be highly improved. New transformants possess erythromycin resistance, such that these transformants were selected on LB medium agar plates with $10 \mu \mathrm{g} / \mathrm{mL}$ erythromycin [18].

Surfactin is a lipopeptide of seven modules that are assembled by NRPS A-, PCP-, C-, and modifying domains (Fig. 1). This antibacterial lipopeptide must be linearly 


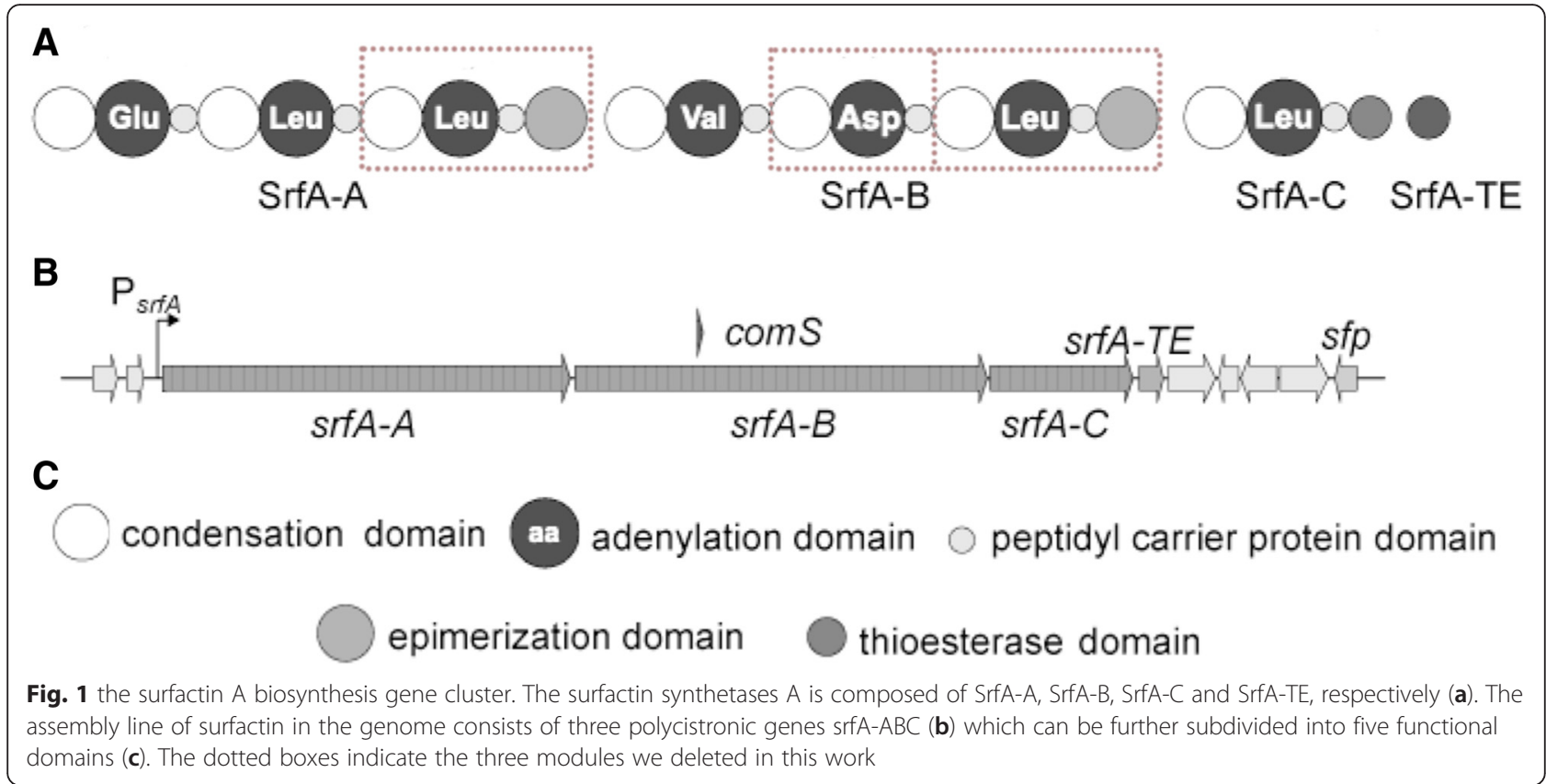

arranged, synthesized, and cyclized into the final assembly of seven amino acids and a $\beta$-hydroxy fatty acid chain. Knocking out one of the modules in NRPS gene clusters produces a lipopeptide lacking one amino acid.

Gene exchange is a two-step replacement procedure, as described previously [19]. Resistance genes were replaced in two steps and recombinant strains sensitive to antibiotics (Fig. 2). In the first step, the gene recombinant plasmid from B. subtilis strains was cultured in LB medium at $37{ }^{\circ} \mathrm{C}$. The homologous sequences were within the target gene plasmid and the entire plasmid inserted into the genome via a single crossover. In Fig. 2, crossed lines indicate the position of a single crossover and the diagonal block and little dots indicate homologous fragment positions. In the second step, the above-described integrands took place in a single exchange; the second exchange occurred on the chromosome in a parental or homologous sequence at $30^{\circ}$ $\mathrm{C}$ within $48 \mathrm{~h}$ and finally expelled the plasmid [20]. In Fig. 2, the diagonal block on the plasmid and genome was successfully integrated by the initial and second single crossovers, such that the little dots in the block occurred between the plasmid and genome. Colonies with deleted surfactin modules exhibited the erythromycin sensitive phenotype, which was then used to detect the desired genotype. Finally, sensitive clones were obtained and verified by PCR. These erythromycin gene of knockout mutants could not amplify this resistance gene but could amplify upstream and downstream sequences of homologous gene knockout mutants (amplified sequence could not contain the knockout gene sequence).

\section{Culture conditions for obtaining surfactins}

B. subtilis strains were inoculated into $250-\mathrm{mL}$ flasks containing $100 \mathrm{~mL}$ of LB medium and cultured at $37^{\circ} \mathrm{C}$ for $24 \mathrm{~h}$ with $180 \mathrm{rpm}$ shaking as a preculture. A $5 \%$ (by vol) preculture was inoculated into a $500-\mathrm{mL}$ flask containing $200 \mathrm{~mL}$ of Landy medium [15], and the wildtype and modified surfactin produced by culturing at $30{ }^{\circ} \mathrm{C}$ with $180 \mathrm{rpm}$ shaking for $72 \mathrm{~h}$.

\section{Extraction of a novel surfactin}

After cultivation, a culture was centrifuged at $11000 \times \mathrm{g}$ for $15 \mathrm{~min}$ to remove bacterial cells. The supernatant $\mathrm{pH}$ was adjusted to 2.0 by adding $6 \mathrm{~N} \mathrm{HCL}$ until the supernatant produced a precipitate. The supernatant was then centrifuged at $11000 \times \mathrm{g}$ for $10 \mathrm{~min}$ and the precipitate collected [21]. The precipitate was then resuspended in methanol several times with subsequent centrifugation. Finally, the $\mathrm{pH}$ was adjusted to 7.0 using $6 \mathrm{~N} \mathrm{NaOH}$ to obtain an extract dissolved in methanol.

\section{Identification of a novel surfactin}

A lipopeptide surfactin was extracted as described previously [22]. The extracts were analyzed by HPLC/MS (Hewlett Packard 1100 Series C8 column, HewlettPackard Co., Palo Alto, CA, USA) and monitored at $210 \mathrm{~nm}$ as well as in negative-ion mode over the $\mathrm{m} / \mathrm{z}$ range from 500 to 1200 . The solvent gradient profile used buffers A and B (0.05\% aqueous formic acid and $0.045 \%$ methanolic formic acid, by vol, respectively) at a flow rate of $0.3 \mathrm{~mL} / \mathrm{min}$, with sample elution starting with $70 \%$ buffer $\mathrm{B}$, followed by a linear gradient to $100 \%$ buffer B over 30 min. 


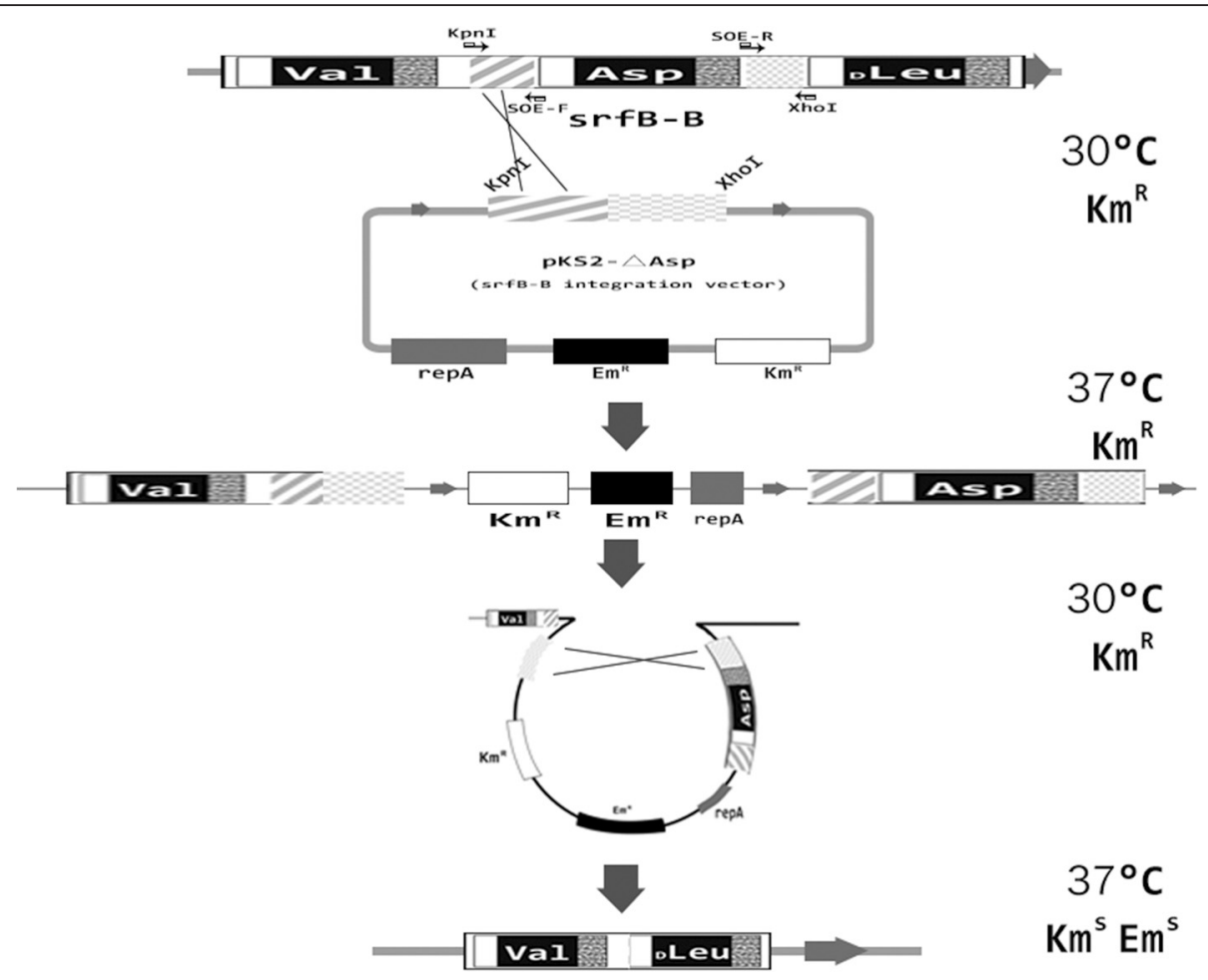

Fig. 2 Knockout strategy of marker-free gene. Note that recombination may occur, both at the upstream fragment of the target gene, as shown below, and at the downstream fragment. In both cases, the final connection result of the chromosome is the same thing. All of intermediation process was identified by polymerase chain reaction

All samples were analyzed by continuous infusion into the LTQ $^{\circ} 7$ Tesla FTICR mass spectrometry ion trap (LTQ-FT, Thermo Fischer Scientific Inc., Waltham, MA, USA) equipped with a Triversa Nanomate nanoESI ion source (Advion Biosciences Corp., Ithaca, NY, USA) [23]. Samples were detected under negative ion mode (mass range, 150-1500) using the following parameters: ion spray voltage at $2.5 \mathrm{kV}$, sheath gas at 20 units, capillary temperature at $300{ }^{\circ} \mathrm{C}$, capillary voltage at $41 \mathrm{~V}$, and tube lens at $110 \mathrm{~V}$. Xcalibur software was used for visualization of high-resolution spectral profile data (Thermo Fischer Scientific, Inc., 2nd Edition SP2) and the exact patterns of $\mathrm{m} / z$ values obtained.

\section{Biological activity analysis of novel surfactin}

Surfactin hemolytic activity was analyzed using blood-agar plates [24]. In brief, activity was detected on commercial blood agar using the Oxford Cup for hemolytic activity detection. The ability of products from bacterial strains to inhibit the growth of various indicator organisms by the agar well diffusion method was a qualitative determination [25]. Pre-poured agar media plates were spread with $10^{7} \mathrm{CFU} /$ $\mathrm{mL}$ of the respective indicator organism and allowed to dry. Wells of $6.8 \mathrm{~mm}$ diameter were cut in the plates using a sterile steel borer and filled with $24 \mathrm{~h} \mathrm{LB}$ culture filtrate
$(60 \mu \mathrm{L})$ of each isolate. After incubation under appropriate conditions, the diameter of the inhibition zone was measured by using calipers. B. pumilus strains were mixed in LB agar plates, and surfactin A and one of three novel surfactin extracts added into the plates using the $6.8-\mathrm{mm}$ punch method to detect lipopeptide antibiotic activity. Filamentous growth of $F$. moniliforme were mixed in potato dextrose agar (PDA) plates, and antibacterial activity measured as described previously. Biologically active substances were isolated and purified by HPLC to yield relatively pure products. Under vacuum conditions, the same concentration ratio and sample concentration were obtained for these isolates and the biological activity analyzed. The diameters of cleared zones were measured and are shown in Table 3. Each sample was treated in triplicate and the results expressed as means $\pm \mathrm{SD}$.

According to the National Committee for Clinical Laboratory Standards (NCCLS), the minimum inhibitory concentrations (MICs) of purified novel surfactin were detected by the 96-plate microbroth method [26]. Final concentrations of novel surfactin in mixtures ranged from 12.5 to $800 \mu \mathrm{g} / \mathrm{mL}$. MICs were measured using an ELISA analyzer after incubation of bacteria at $37{ }^{\circ} \mathrm{C}$ for $20 \mathrm{~h}$ and the fungus at $28{ }^{\circ} \mathrm{C}$ for $24 \mathrm{~h}$. 
Inhibitory ability of $\left[\Delta \mathrm{Leu}^{6}\right]$ surfactin on $\mathrm{F}$. moniliforme hyphae and spores

Equal volumes of $6.25,12.5,25,50,100,200$, and $400 \mu \mathrm{g} / \mathrm{mL}$ of $\left[\Delta \mathrm{Leu}^{6}\right]$ surfactin were separately added into PDA medium. Then, 5-mm hyphae discs of F. moniliforme were placed at the PDA media centers. The diameters of the hyphal extent were detected by the decussation method after incubation for $7 \mathrm{~d}$ at $28{ }^{\circ} \mathrm{C}$ and then the inhibition ability rate calculated. At the same time, after washing hyphae of $F$. moniliforme using $10 \mathrm{~mL}$ of saline solution containing Tween 20 ( $0.1 \%$ by vol), the spore numbers were detected using a hemocytometer. A sample with sterile PBS was used as a control and each group was evaluated in triplicate.

\section{Influence of $F$. moniliforme hyphae by $\left[\Delta \mathrm{Leu}^{6}\right]$ surfactin}

Cells at $1 \times 10^{6} \mathrm{cell} / \mathrm{mL}$ of $F$. moniliforme were cultured on individual PDA culture plates at $28{ }^{\circ} \mathrm{C}$ for $5 \mathrm{~d}$. Mycelia were harvested from cultures and prepared by washing with sterile saline solution $(0.85 \% \mathrm{NaCl}$, by wt) and then centrifuged at $3,000 \times \mathrm{g}$ for $3 \mathrm{~min}$. Then, hyphae were picked from PDA plates, placed on the concave side, and $\left[\Delta \mathrm{Leu}^{6}\right]$ surfactin solution added to a final concentration of $50 \mu \mathrm{g} / \mathrm{mL}$. The hyphae were cultured in moisturizing gauze on Petri dishes and, after incubation for 1,2 , or $4 \mathrm{~h}$ at $28{ }^{\circ} \mathrm{C}$, samples were collected for inspection by ordinary optical microscopy. Sterile PBS was used as a control.

\section{SEM and TEM}

Hyphae were washed in $0.1 \mathrm{M}$ phosphate buffered saline (PBS, pH 7.2), and fixed using $2.5 \%$ glutaraldehyde at $4{ }^{\circ} \mathrm{C}$ for $24 \mathrm{~h}$. The resulting sediments were rinsed three times with $0.02 \mathrm{M}$ PBS, fixed with $2 \%$ osmium tetraoxide for $2 \mathrm{~h}$ at room temperature, and dehydrated through a sequence of 30,50,70, and $90 \%$ aqueous ethanol solutions. Morphological observations of samples were carried out using a scanning electron microscope (Hitachi High Technologies America, Inc., Shaumburg, IL, USA Inc.) operating at $30.0 \mathrm{kV}$.

A modified TEM method was used, as previously described [27]. Hyphae were fixed using $2.5 \%$ glutaraldehyde at $4{ }^{\circ} \mathrm{C}$ for $24 \mathrm{~h}$ and, after treatment with $2 \%$ osmium tetraoxide, ethanol, acetone, and epoxy, 100$\mathrm{nm}$-thick specimens were cut using a microtome (HM 505E, Microm GmbH, Walldorf, Germany). Specimens were then observed by TEM (JEM-1230, Jeol Ltd., Tokyo, Japan).

\section{Spore analysis by flow cytometry}

Spore suspensions of $F$. moniliforme at $1 \times 10^{6} \mathrm{cell} / \mathrm{mL}$ were provided with $\left[\Delta \mathrm{Leu}^{6}\right]$ surfactin to a final concentration of $12.5,25$, or $50 \mu \mathrm{g} / \mathrm{m}$ and cultured at $28^{\circ} \mathrm{C}$ for 1-2 h. After incubation, the spores were collected, centrifuged (5000 $\times \mathrm{g}$ for $3 \mathrm{~min})$, and washed twice with $0.02 \mathrm{M}$ PBS. The retrieved spores were suspended, adjusted to $1 \times 10^{6} \mathrm{cell} / \mathrm{mL}$, dyed by adding $10 \mu \mathrm{L}$ of $1 \mathrm{mg} /$ $\mathrm{mL}$ of propidium iodide solution, and then incubated at $4{ }^{\circ} \mathrm{C}$ in darkness for 15 min [28]. A Becton Dickinson FACScalibur (BD Biosciences, Inc., San Jose, CA, USA) was used for flow cytometry analysis and FCS Express 4 software used for data analysis. Counts of 10,000 per sample were obtained and each sample analyzed in triplicate. The percentage of spore cell damage was calculated using the following formula: Cell damage $(\%)=\{$ (the number of stained cells M2)/(the number of non-stained cells M1 + the number of stained cells M2) $\} \times 100 \%$.

\section{Impact of $\left[\Delta \mathrm{Leu}^{6}\right]$ surfactin on $F$. moniliforme nucleic acids and proteins}

Spores of $F$. moniliforme at $1 \times 10^{6} \mathrm{cell} / \mathrm{mL}$ were treated with 25 and $50 \mu \mathrm{g} / \mathrm{mL}$ of $\left[\Delta \mathrm{Leu}^{6}\right]$ surfactin and then incubated in PDA medium at $28{ }^{\circ} \mathrm{C}$ for $1-4$ hours. Spores not treated with $\left[\Delta \mathrm{Leu}^{6}\right]$ surfactin served as controls. After incubation, the supernatant was retrieved from samples by centrifugation at $5000 \times \mathrm{g}$ for $3 \mathrm{~min}$. Finally, the samples' $\mathrm{OD}_{260}$ and $\mathrm{OD}_{280}$ levels were measured to assess the leakage of nucleic acids and proteins from $F$. moniliforme [29].

Table 2 Primers used in this study. Underlined sequences are complementary sequences to adjacent segments

\begin{tabular}{|c|c|}
\hline Oligonucleotide & Sequence \\
\hline 5'srfA-A- $\Delta$ Leu-up-F & 5'-CAAGATACGTATCCT-3' \\
\hline 3'srfA-A-ALeu-SOE-up-R & $\begin{array}{l}\text { 5'-CAGCATTCCCTCCTGAG }^{\text {TCGGAAGCGTCAG-3' }}\end{array}$ \\
\hline 5'srfA-A-ALeu-SOE-down-F & $\begin{array}{l}5^{\prime} \text {-CTGACGCTTCCGACTC } \\
\text { AGGAGGGAATGCTG-3' }\end{array}$ \\
\hline 3'srfA-A-ALeu-down-R & 5'-CCACTTGATGTAATC-3' \\
\hline 5'srfA-B- $\triangle$ Asp -up-F & 5'-CAGCATTATCCTGTATC-3' \\
\hline 3'srfA-B- $\triangle$ Asp-SOE-up-F & $\begin{array}{l}\text { 5'-AGCAGACGCCTCCATTG } \\
\text { GCCGCTCGAAATC-3' }\end{array}$ \\
\hline 5'srfA-B- $\triangle$ Asp-SOE-down-F & $\begin{array}{l}\text { 5'-GATTTCGAGCGGCCAATG }^{\text {GAGGCGTCTGCT-3' }} \\
\text { AGT }\end{array}$ \\
\hline 3'srfA-B- $\triangle$ Asp-down-R & 5'-TTGCCAAACGGCG-3' \\
\hline 5'srfA-B- $\Delta$ Leu-up-F & 5'-ATGGAGGCGTCTGCT-3' \\
\hline 3'srfA-B-ALeu-SOE-up-F & $\begin{array}{l}\text { 5'-GCTAAATTGACTCATTTG } \\
\text { CCAAACGGCGAA-3' }\end{array}$ \\
\hline 5'srfA-B- $\Delta$ Leu-SOE-down-R & $\begin{array}{l}5^{\prime} \text {-TTCGCCGTTGGCAAAT } \\
\text { GAGTCAATTTAGC-3' }\end{array}$ \\
\hline 3'srfA-B-ALeu-down-R & 5'-CGGCTITTGTTCGCG-3' \\
\hline 5'pKS-1058-ERM-F & $\begin{array}{l}\text { 5'-CTTGGGCGTGTTCATT } \\
\text { GCTTG-3' }\end{array}$ \\
\hline 3'pKS-1058-ERM-R & $\begin{array}{l}\text { 5'-GGTTCGTGTTCGTGCTG } \\
\text { ACTTG-3' }\end{array}$ \\
\hline
\end{tabular}




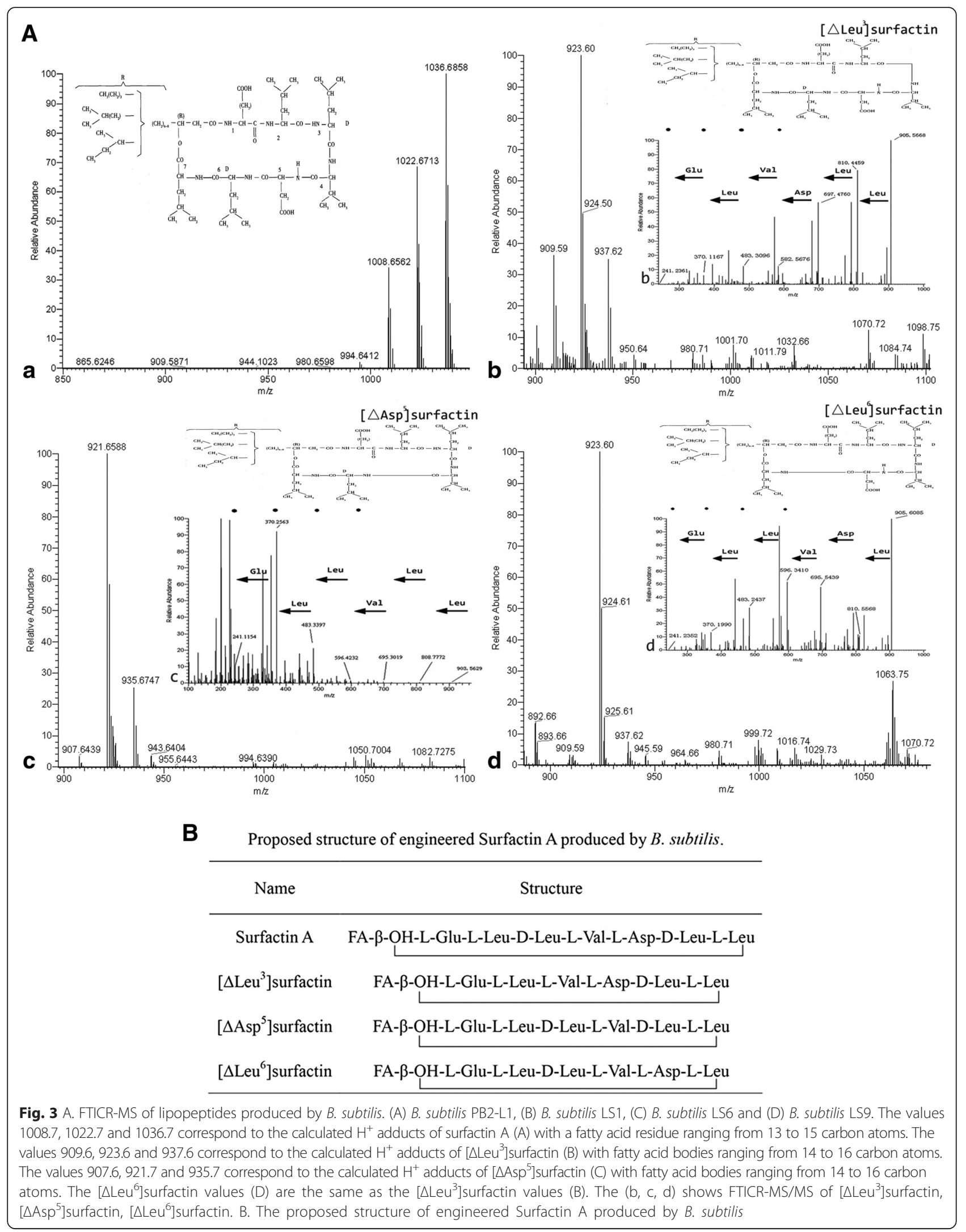




\section{DNA binding assay by $\left[\Delta\right.$ Leu $\left.^{6}\right]$ surfactin}

DNA binding was detected by gel retardation experiments, as described previously [30]. F. moniliforme DNA was mixed with different concentrations of $\left[\Delta \mathrm{Leu}^{6}\right]$ surfactin and surfactin with $10 \mu \mathrm{L}$ of binding buffer (10 $\mathrm{mM}$ Tris- $\mathrm{HCl}$ and $1 \mathrm{mM}$ EDTA buffer, $\mathrm{pH}$ 8.0). The mixed samples were incubated for $1 \mathrm{~h}$ and then the mixtures assessed using $1.0 \%$ agarose gel electrophoresis.

\section{Statistical analysis}

Statistical analyses were determined using SPSS software (SPSS version 17.0, IBM Corp., Armonk, NY, USA). All experiments were performed in triplicate and data expressed as mean \pm standard deviation (SD). A $p$ value of $<0.05$ was considered significant.

\section{Results}

Reconstitution of novel surfactin synthetase

The first step in SrfA-A and SrfA-B subunit rearrangement was the deletion of $D$-Leu-, Asp-, and $D$-Leu- modules. Deletion of the SrfA-A-Leu, SrfAB-Asp, or SrfA-B-Leu modules in the srfA-A or srfA-B subunit was completed using the marker-free method (Fig. 2). In the first deletion, a $4.4 \mathrm{~kb}$ fragment of SrfA-A-Leu was deleted with an upstream and downstream integration by means of the temperature sensitive shuttle plasmid pKS2-SrfA-A$\Delta$ Leu. The deleted fragment located between 1050 and 2090 (the deleted fragment of srfA-A subunit corresponding to amino acid positions) in the srfA-A subunit. The second deletion mutant was produced using the disruption plasmid pKS2-SrfA-B- $\Delta$ Asp. This disruption plasmid deleted the SrfA-B-Asp module from position 1196 to 2092, which encoded an $L$-Asp-incorporating module in the srfA-B subunit. The third module mutant introduced a deletion in the SrfA-B-Leu module from position 2093 to 3574, which encoded the $D$-Leu-incorporating module in the srfA-B subunit.

The upstream and downstream sequences of the deleted fragment were amplified using PCR, using the corresponding primers, and the occurrence of homologous recombination demonstrated. The resulting plasmid-less clones were screened for the desired modifications using colony PCR analysis. In deletion mutants, the erythromycin resistance gene in the chromosome was removed at the last step and, thus, the erythromycin resistance gene could not be amplified from the deletion mutants by PCR.

Using amplification primer pairs, 5 'srfA-A- $\Delta$ Leu-up-F and 3 'srfA-A- $\Delta$ Leu-down-R, and 5'pKS-1058-ERM-F and 3'pKS-1058-ERM-R (Table 2), the target band was $1107 \mathrm{bp}$, which described mutants containing the upstream and downstream sequence of the Leu module. PCR validation confirmed that, at the molecular level, the deleted module sequence was indeed not in the mutant genome. The deletion of SrfA-B-Asp and SrfA-B-Leu modules was also in accordance with the above methods.

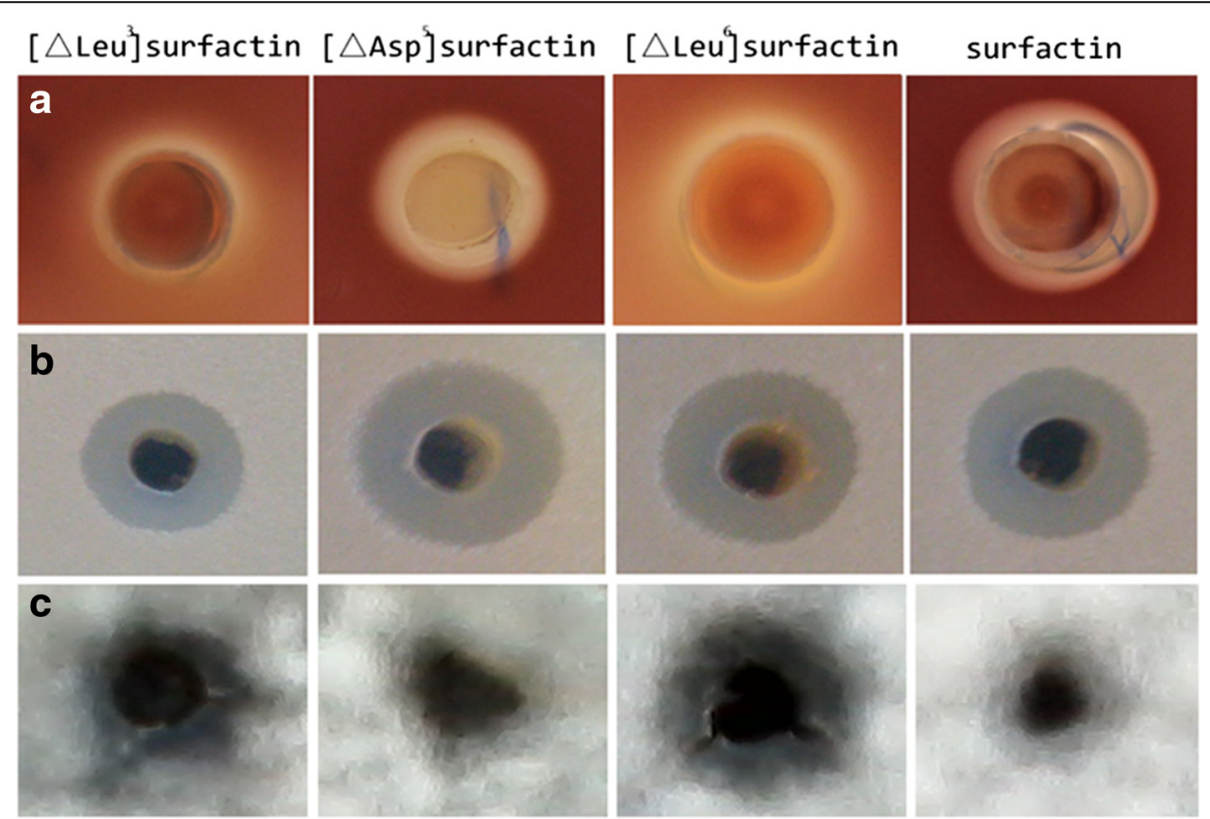

Fig. 4 Analysis of bioactivity activity of novel surfactins. a The activity of hemolysis after incubation on blood agar plates for $24 \mathrm{~h}$ at $37^{\circ} \mathrm{C}$. b Inhibition of Bacillus pumilus after incubation on LB agar plates for $12 \mathrm{~h}$ at $37^{\circ} \mathrm{C}$. (C) Inhibition of Fusarium moniliform after incubation on PDA plates for $48 \mathrm{~h}$ at $28^{\circ} \mathrm{C}$. a was the hemolysis test; (b) and (c) were the antibacterial and antifungal test 
Table 3 Diameter of cleared zones of surfactins exhibiting biological activity

\begin{tabular}{lllll}
\hline The diameters of cleared zone $(\mathrm{mm})$ & {$\left[\Delta \mathrm{Leu}^{3}\right]$ surfactin } & {$\left[\Delta \mathrm{Asp}^{5}\right]$ surfactin } & {$\left[\Delta\right.$ Leu $\left.^{6}\right]$ surfactin } & Surfactin \\
\hline Hemolysis rings & $8.29 \pm 0.28$ & $11.75 \pm 0.37$ & $7.87 \pm 0.17$ & $11.62 \pm 0.45$ \\
B. pumilus & $17.14 \pm 0.16$ & $19.71 \pm 0.85$ & $19.17 \pm 0.16$ & $19.36 \pm 0.23$ \\
F. moniliforme & $10.68 \pm 0.50$ & $7.04 \pm 0.22$ & $13.12 \pm 0.49$ & $7.09 \pm 0.15$ \\
\hline
\end{tabular}

\section{HPLC-MS analysis of novel surfactin production}

Culture supernatants were acidified and the resulting precipitates extracted with methanol and analyzed by reverse-phase HPLC. Wild-type surfactin A was detected as a group of four major peaks representing fatty acid length polymorphism. Novel forms of surfactin, $\left[\Delta \mathrm{Leu}^{3}\right]$ surfactin, $\left[\Delta \mathrm{Asp}^{5}\right]$ surfactin, and $\left[\Delta \mathrm{Leu}^{6}\right]$ surfactin, were observed with retention times of 17.3, 18.7, and $17.8 \mathrm{~min}$, respectively. The final yield was $\sim 0.82,1.35$, and $0.96 \mathrm{mg} / \mathrm{L}$, respectively. Because the novel surfactin secretions by strain B. subtilis LS1 appeared to be more hydrophobic than native surfactin $\mathrm{A}$, in the LC atlas, the LS6 retention time by comparison was later than the retention time of LS1 and LS9.

The lipopeptide biosyntheses of mutant B. subtilis LS1, LS6 and LS9 were compared and HPLC results showed that the novel surfactin yields from these mutant strains were relatively low. Thus, the three novel surfactin structures were analyzed and identified by FTICR-MS, a highly sensitive detection method.

The molecular mass of surfactin A in the range $\mathrm{m} / \mathrm{z}$ 1008-1036 was similar to previous published molecular masses (Fig. 3a) [31], and its fatty chain length was 13-15 carbon atoms. The molecular mass of $\left[\Delta \mathrm{Leu}^{3}\right]$ surfactin was in the range of $\mathrm{m} / z$ 909-937 (Fig. 3b). The other two novel surfactins, $\left[\Delta \mathrm{Asp}^{5}\right]$ surfactin and $\left[\Delta \mathrm{Leu}^{6}\right]$ surfactin, were also confirmed by mass spectra of ions at $m / z \quad 907-935$ and 909-937 (corresponding to $\mathrm{H}^{+}$adducts), respectively (Fig. 3c and $\mathrm{d}$ ). Overall the chain lengths of these three novel surfactin derivatives were in the range of 14 to 16 carbon atoms, such that surfactin $A$ and the three novel surfactin derivatives showed different chain lengths in their $\beta$-hydroxy fatty acids.
Figure $3 \mathrm{~b}, \mathrm{c}$, and $\mathrm{d}$ show the fracture fragments from $\left[\Delta \mathrm{Leu}^{3}\right]$ surfactin, $\left[\Delta \mathrm{Asp}^{5}\right]$ surfactin, and $\left[\Delta \mathrm{Leu}^{6}\right]$ surfactin. $\left[\Delta \mathrm{Leu}^{3}\right]$ surfactin corresponded to $[\mathrm{M}+\mathrm{H}]^{+}$ions of $\mathrm{m} / \mathrm{z}$ 923.6 Da. A deduction of $18 \mathrm{Da}$ occurred because of dehydration by the FTICR-MS/MS conditions. Thus, the initial molecular weight of $\left[\Delta \mathrm{Leu}^{3}\right]$ surfactin was $[\mathrm{M}+\mathrm{H}]^{+}$ions of $m / z$ 905.6. The stepwise cleavage was $L$-leucine (810.4), $D$-leucine (697.5), $L$-aspartic acid (582.6), $L$-valine (483.3), $L$-leucine (370.1), and $L$-glutamic acid (241.2) from $\left[\Delta \mathrm{Leu}^{3}\right]$ surfactin (Fig. $4 \mathrm{~b}$, arrows indicate fragment size and theoretical molecular weight of each amino acid). FTICR-MS/MS results for $\left[\Delta \mathrm{Asp}^{5}\right]$ surfactin and $\left[\Delta \mathrm{Leu}^{6}\right]$ surfactin were marked in the same manner as for $\left[\Delta \mathrm{Leu}^{3}\right]$ surfactin (Fig. $3 \mathrm{c}$ and d). FTICRMS/MS results indicated that fracture fragments of these three novel surfactin were consistent with the predicted patterns.

\section{Bioactivity analysis of novel surfactins}

Lipopeptide surfactin A causes hemolysis and inhibits a broad range of microorganisms, but it does not inhibit filamentous fungi. Blood agar plates and surfactin extracts from $B$. subtilis PB2-L1, LS1, LS6, and LS9 were cocultured at $37{ }^{\circ} \mathrm{C}$ for $24 \mathrm{~h}$. Hemolytic activity was detected using the Oxford Cup method. $\left[\Delta \mathrm{Leu}^{3}\right]$ surfactin produced a clear hemolytic zone surrounding extracts of culture supernatants (Fig. 4a). In contrast, no hemolysis was visible for $\left[\Delta \mathrm{Leu}^{3}\right]$ surfactin and $\left[\Delta \mathrm{Leu}^{6}\right]$ surfactin. However, the hemolytic zone of methanol extracts from $B$. subtilis LS6 was bigger than that for B. subtilis PB2-L1.

Growth inhibitions of microorganisms by the three novel surfactins were compared by incubating the mixtures at $37^{\circ} \mathrm{C}$ for $1 \mathrm{~d}$. The inhibition zone of $\left[\Delta \mathrm{Asp}^{5}\right]$ surfactin was very obvious, presenting a clear, transparent

Table 4 The minimum inhibitory concentrations (MICs) of lipopeptide antibiotics produced by Bacillus subtilis

\begin{tabular}{lllll}
\hline Indicator strain & MIC $(\mu \mathrm{g} / \mathrm{mL})$ & & \\
\cline { 2 - 5 } & {$\left[\Delta \mathrm{Leu}^{3}\right]$ surfactin } & {$\left[\Delta\right.$ Asp $\left.^{5}\right]$ surfactin } & 50 & SurfactinA \\
\hline Bacillus cereus AS1.1846 & 50 & 25 & 50 & 100 \\
Staphylococcus aureus AS1.2465 & 50 & 25 & 400 & 50 \\
Micrococcus luteus CMCC28000 & 200 & 50 & 500 & 200 \\
Pseudomonas fluorescens AS1.1802 & 600 & 400 & 300 & 400 \\
Salmonella enteritidis CICC21527 & 400 & 200 & 50 & 200 \\
Bacillus subtilis ATCC9943 & 50 & 25 & 50 & 100 \\
Fusarium moniliforme ATCC3893 & 200 & ND & 50 & ND \\
\hline
\end{tabular}

ND means no detected of the minimum inhibitory concentrations for indicator strain 
Table 5 The inhibitory ability of $\left[\Delta \mathrm{Leu}^{6}\right]$ surfactin for hyphae and sporulation of Fusarium moniliforme

\begin{tabular}{|c|c|c|c|c|}
\hline $\begin{array}{l}{\left[\Delta \text { Leu }^{6}\right] \text { surfactin }} \\
\text { concentration } \mu \mathrm{g} / \mathrm{mL}\end{array}$ & $\begin{array}{l}\text { Colony diameter } \\
(\mathrm{mm})\end{array}$ & $\begin{array}{l}\text { Inhibition of hyphae } \\
\text { growth (\%) }\end{array}$ & $\begin{array}{l}\text { The number of } \\
\text { spores }\left(\times 10^{6} / \mathrm{ml}\right)\end{array}$ & $\begin{array}{l}\text { Inhibition } \\
\text { of spores (\%) }\end{array}$ \\
\hline $\mathrm{CK}$ & $39.58 \pm 0.35^{\mathrm{a}}$ & 0 & $30.1 \pm 2^{\mathrm{a}}$ & 0 \\
\hline 6.25 & $31.57 \pm 0.22^{\mathrm{a}}$ & 20.23 & $25.2 \pm 1.5^{\mathrm{a}}$ & 16.27 \\
\hline 12.5 & $27.65 \pm 0.13^{b}$ & 30.14 & $22.5 \pm 1^{b}$ & 25.24 \\
\hline 25 & $21.67 \pm 0.36^{c}$ & 45.25 & $20.3 \pm 0.6^{c}$ & 32.55 \\
\hline 50 & $17.75 \pm 0.61^{d}$ & 55.15 & $10.7 \pm 0.2^{d}$ & 64.45 \\
\hline 100 & $9.83 \pm 0.37^{\mathrm{e}}$ & 75.16 & $3.5 \pm 0.5^{\mathrm{e}}$ & 88.37 \\
\hline 200 & $1.63 \pm 0.07^{f}$ & 95.88 & $0.5 \pm 0^{f}$ & 98.33 \\
\hline 400 & ND & 100 & ND & 100 \\
\hline
\end{tabular}

ND means no detected of hyphae or sporulation for Fusarium moniliforme. a, b, c, d, e, f letters indicated significant differences $(P$ value $<0.01)$

circle around the hole (Fig. 4b). In contrast, surfactin A caused less fungal inhibition. In fungal inhibition experiments using the three novel surfactin derivatives, $\left[\Delta \mathrm{Leu}^{3}\right]$ surfactin and $\left[\Delta \mathrm{Leu}^{6}\right]$ surfactin exhibited the ability to inhibit fungi, and surfactin $\mathrm{A}$ and $\left[\Delta \mathrm{Asp}^{5}\right]$ surfactin did not show such ability. These results indicated that $\left[\Delta \mathrm{Leu}^{6}\right]$ surfactin and $\left[\Delta \mathrm{Leu}^{3}\right]$ surfactin possessed inhibitory ability for $F$. moniliforme hyphae, compared with surfactin (Table 3). For example, the colony diameters of Fusarium moniliforme were $13.12 \pm 0.49 \mathrm{~mm}$ for $\left[\Delta \mathrm{Leu}^{6}\right]$ surfactin, and the surfactin showed no inhibition of $F$. moniliforme hyphae growth.

As it can be seen from Table 4, a molecular recombinant method was employed to alter the surfactin gene cluster, and the properties of the resulting novel surfactins were found to be altered, after production by fermentation. $\left[\Delta \mathrm{Leu}^{6}\right]$ surfactin exhibited the ability to inhibit fungi, and the MIC of $\left[\Delta \mathrm{Asp}^{5}\right]$ surfactin was higher than surfactin A. The MIC of $\left[\Delta \mathrm{Leu}^{6}\right]$ surfactin for F. moniliforme was $50 \mu \mathrm{g} / \mathrm{mL}$. These results revealed that the lack of leucine in surfactin reduced surfactin hemolytic activity while retaining antibacterial activity. At the same time, hemolytic and antibacterial activities were increased because of the lack of aspartic acid in surfactin.

\section{Inhibitory ability of $\left[\Delta L_{\text {eu }}{ }^{6}\right]$ surfactin for $F$. moniliforme hyphae and spores}

The results shown in Table 5 revealed that $\left[\Delta \mathrm{Leu}^{6}\right]$ surfactin's inhibitory ability for $F$. moniliforme hyphae and spores increased was concentration dependent. $\left[\Delta \mathrm{Leu}^{6}\right]$ surfactin at $6.25 \mu \mathrm{g} / \mathrm{mL}$ exhibited 20.23 and $16.27 \%$ (both $p<0.01$ ) inhibitory ability for hyphae and spores, respectively. However, $50 \mu \mathrm{g} / \mathrm{mL}$ of $\left[\Delta \mathrm{Leu}^{6}\right]$ surfactin showed stronger inhibitory ability (55.15 and $64.45 \%$, respectively). [ $\left.\Delta \mathrm{Leu}^{6}\right]$ surfactin at $400 \mu \mathrm{g} / \mathrm{mL}$ completely inhibited hypha and spore growth. Thus, $\left[\Delta \mathrm{Leu}^{6}\right]$ surfactin significantly inhibited F. moniliforme growth.

\section{Influence of $F$. moniliforme hyphae by [ $\left.\Delta \mathrm{Leu}^{6}\right]$ surfactin}

Compared with control hyphae, many small vesicles were observed on numerous mycelia after treatment with $50 \mu \mathrm{g} / \mathrm{mL}\left[\Delta \mathrm{Leu}^{6}\right]$ surfactin for $1 \mathrm{~h}$ (Fig. $5 \mathrm{~b}$ ); there were no observable vesicles in control hyphae. After

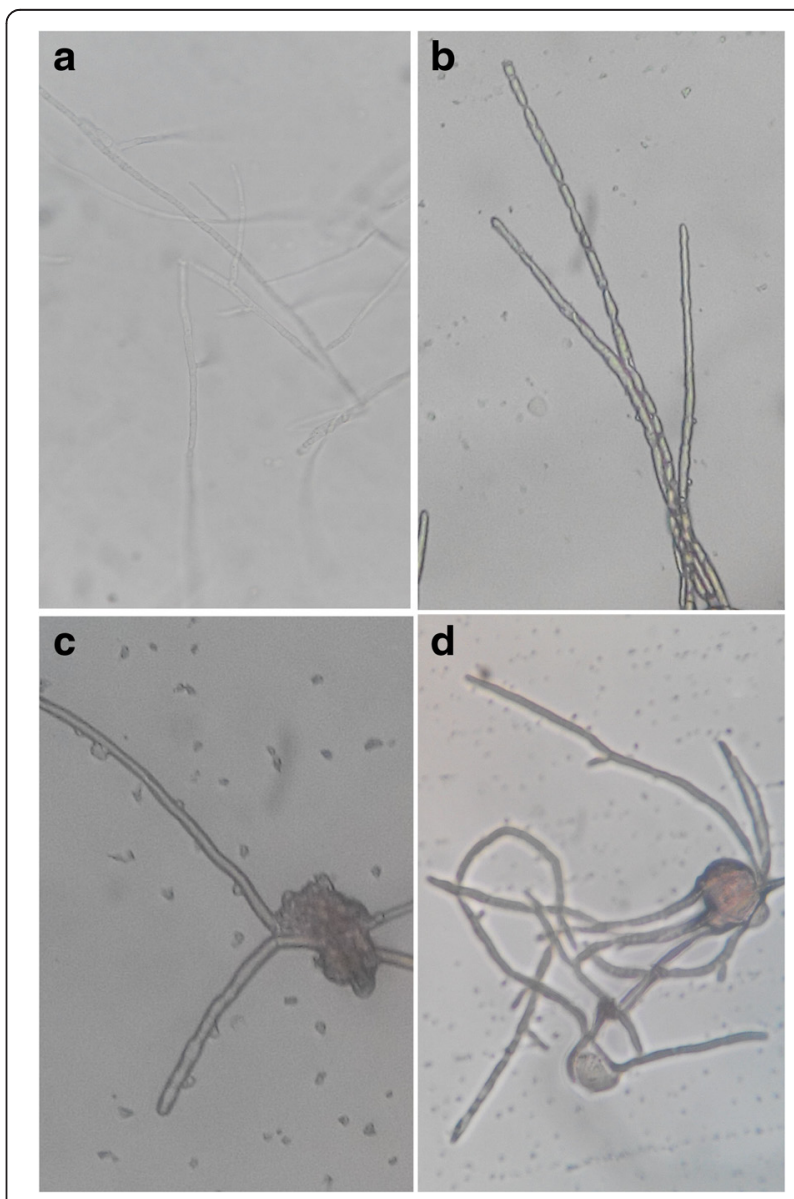

Fig. $5800 \times$ micrographs of optical microscope for hyphe of Fusarium moniliforme treated by $\left[\Delta \mathrm{Leu}^{6}\right]$ surfactin. $\mathbf{a}$ the hypha treated without $\left[\Delta \mathrm{Leu}^{6}\right]$ surfactin; (b) the hypha treated with $50 \mu \mathrm{g} / \mathrm{mL}$ of $\left[\Delta \mathrm{Leu}^{6}\right]$ surfactin for $1 \mathrm{~h}$; (c) the hypha treated with $50 \mu \mathrm{g} / \mathrm{mL}$ of [ $\left.\Delta \mathrm{Leu}^{6}\right]$ surfactin for $2 \mathrm{~h}$; (d) the hypha treated with $50 \mu \mathrm{g} / \mathrm{mL}$ of [ $\left.\Delta \mathrm{Leu}^{6}\right]$ surfactin for $4 \mathrm{~h}$ 
treatment for $2 \mathrm{~h}$, vesicles on mycelia became large and a relatively large projections emerged in the central regions of mycelia. After treatment for $4 \mathrm{~h}$ (Fig. 5d), the abnormal central mycelial enlargements were ruptured and mycelia appeared as thin strips. This phenomenon was not observed in controls (Fig. 6a).

F. moniliforme hyphal structures were observed by SEM and TEM (Fig. 6). Hyphae treated without $\left[\Delta\right.$ Leu $\left.^{6}\right]$ surfactin grew normally with a straight, smooth appearance (Fig. 6a), while bending and rough structures were observed after treatment with $50 \mu \mathrm{g} / \mathrm{mL}$ of $\left[\Delta \mathrm{Leu}^{6}\right]$ surfactin (Fig. 6b). TEM images of growing, healthy, and normal hyphae, treated without $\left[\Delta \mathrm{Leu}^{6}\right]$ surfactin, showed smooth surfaces and all cellular organelles were visible and in normal arrangements (Fig. 6c). In contrast, although hyphal structures remained intact when treated with $50 \mu \mathrm{g} / \mathrm{mL}$ $\left[\Delta \mathrm{Leu}^{6}\right]$ surfactin, organelles were gathered in clumps and some large vacuoles were noticeable in their central regions (Fig. 6d). SEM and TEM observations indicated that $\left[\Delta \mathrm{Leu}^{6}\right]$ surfactin clearly affected $F$. moniliforme growth.

\section{Impact of $\left[\Delta \mathrm{Leu}^{6}\right]$ surfactin on $F$. moniliforme spores}

In samples treated for $1 \mathrm{~h}$ with a final concentration of $12.5 \mu \mathrm{g} / \mathrm{mL}\left[\Delta \mathrm{Leu}^{6}\right]$ surfactin, a portion of $F$. spores were already stained with fluorescent dye (Fig. 7). With increased surfactin concentration, fluorescent dye staining rapidly increased. Two-hour samples treated with the same concentration did not show increased fluorescent dye spore staining. However, in 25 and $50 \mu \mathrm{g} / \mathrm{mL}\left[\Delta \mathrm{Leu}^{6}\right]$ surfactin treated samples, staining of spores increased significantly. The increase in the number of spores was determined by the intrusion of fluorescent dyes. Thus, these observations revealed that $\left[\Delta \mathrm{Leu}^{6}\right]$ surfactin's effects on F. moniliforme spores also led to damage or apoptosis of spores.

\section{Impact of $\left[\Delta\right.$ Leu $\left.^{6}\right]$ surfactin on the integrity of $F$. moniliforme mycelia}

The effects of a surfactin on mycelium integrity can be reflected in the release of intracellular contents, such as an increased release of nucleic acid and proteins (assessed by changes in $\mathrm{OD}_{260}$ and $\mathrm{OD}_{280}$, respectively).

After treatment of $F$. moniliforme with 25 and $50 \mu \mathrm{g} /$ $\mathrm{mL}$ of $\left[\Delta \mathrm{Leu}^{6}\right]$ surfactin, $F$. cell nucleic acids and proteins were rapidly released into the external bacterial body, detected by spectroscopic absorption analysis of released nucleic acids and proteins (Fig. 8). The $\mathrm{OD}_{260}$ and $\mathrm{OD}_{280}$ of extracellular fluids increased rapidly in samples treated for $2 \mathrm{~h}$ with $50 \mu \mathrm{g} / \mathrm{mL}\left[\Delta \mathrm{Leu}^{6}\right]$ surfactin. After

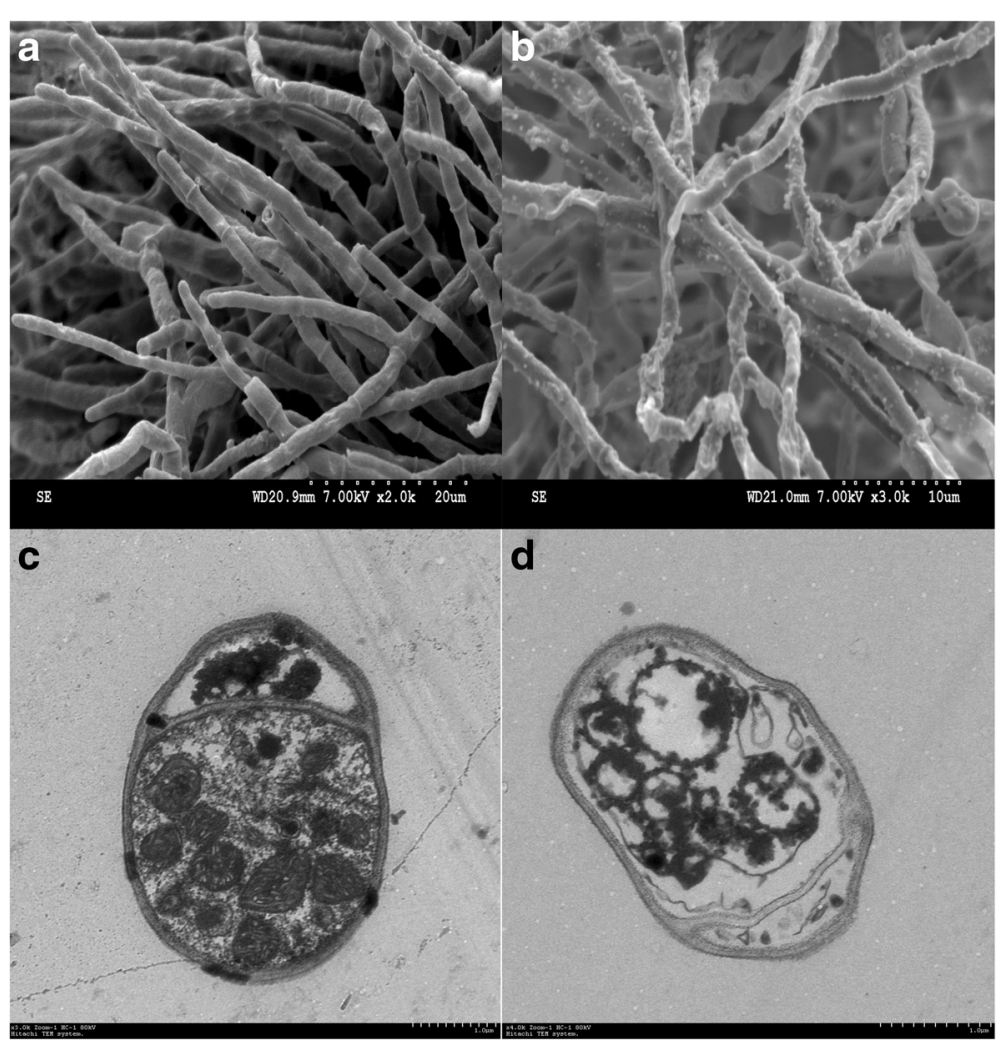

Fig. $6 \mathrm{SEM}$ and TEM micrographs of hyphae of Fusarium moniliforme treated by $\left[\Delta \mathrm{Leu}^{6}\right]$ surfactin. $\mathbf{a}$, the hyphae treated without $\left[\Delta \mathrm{Leu}^{6}\right]$ surfactin (SEM); b, the hyphae treated with $50 \mu \mathrm{g} / \mathrm{mL}$ of $\left[\Delta \mathrm{Leu}^{6}\right]$ surfactin (SEM); $\mathbf{c}$, the hyphae treated without $\left[\Delta\right.$ Leu $\left.^{6}\right]$ surfactin (TEM); $\mathbf{d}$, the hyphae treated with $50 \mu \mathrm{g} / \mathrm{mL}$ of $\left[\mathrm{LLeu}^{6}\right]$ surfactin (TEM) 


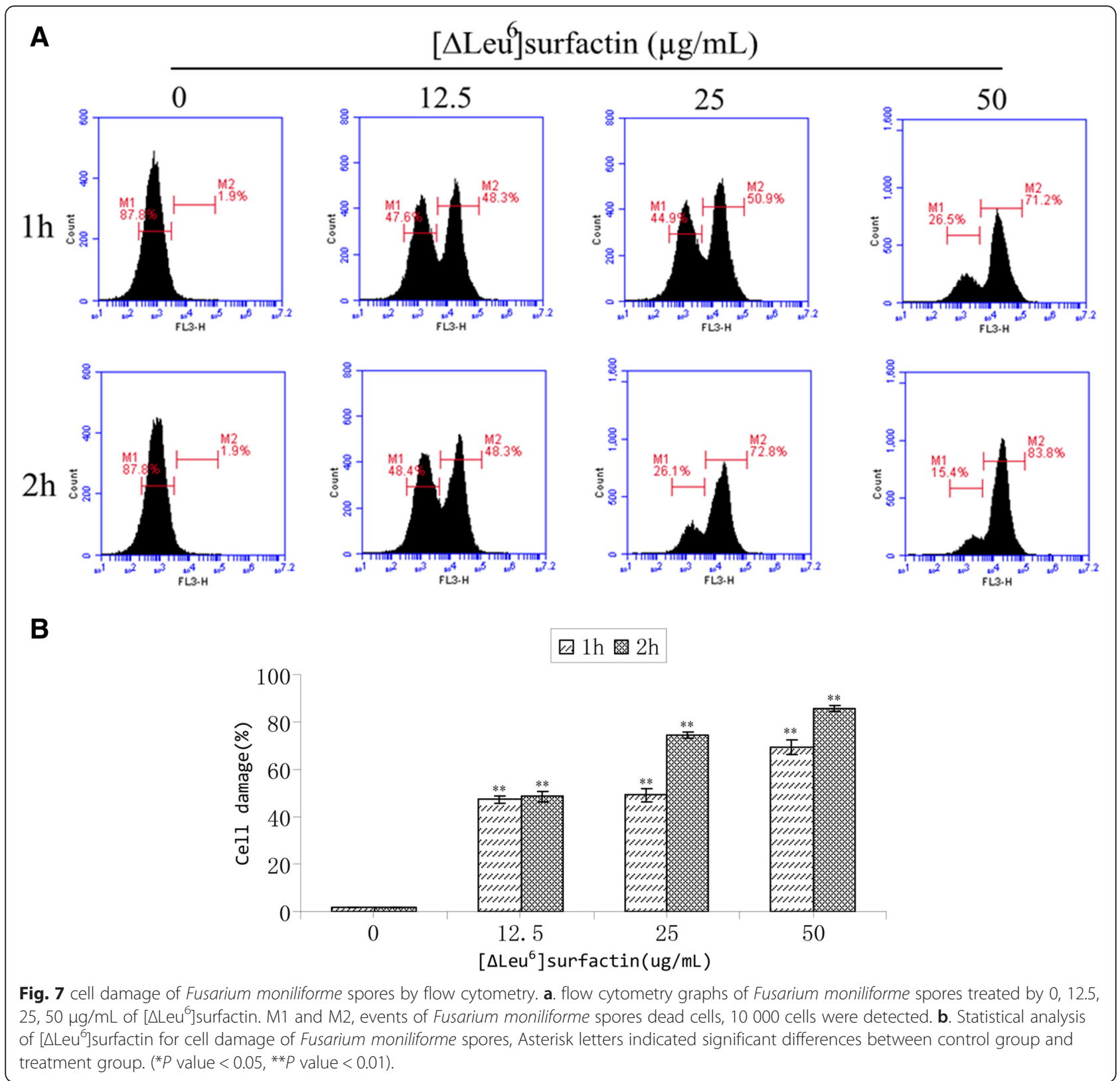

$3 \mathrm{~h}$ of treatment, the $\mathrm{OD}_{260}$ and $\mathrm{OD}_{280}$ reached their maxima and ceased to increase.

\section{DNA binding assay}

With increased antimicrobial lipopeptide concentrations, the binding capacity of $F$. moniliforme DNA gradually strengthened, indicating that $\left[\Delta \mathrm{Leu}^{6}\right]$ surfactin imposed a certain effect on the fungal genome. As shown in Fig. 9, treatment of fungal samples with $200 \mu \mathrm{g} / \mathrm{mL}\left[\Delta \mathrm{Leu}^{6}\right]$ surfactin resulted in the Fusarium genome DNA showing some dispersion. These results showed that surfactin possessed the ability to bind to fungal DNA, with $\left[\Delta \mathrm{Leu}^{6}\right]$ surfactin exhibiting the greatest such ability.

\section{Discussion}

In this study, a method for marker-free knockout of surfactin synthase was adopted and surfactin synthase successfully altered in three different modules. These modules were responsible for the synthesis of leucine and aspartic acid. Some deletion module surfactin derivatives have already been demonstrated, including versions in which the second and last modules of surfactin synthetase were deleted [32, 33]. Schneider et al. have previously reported a different modification method, which relied on molecular surgery within the domains to achieve an exchange of A- units [22]. This approach has been successfully applied to position 7 in surfactin NRPS [34]. From previous reports, the module containing the 

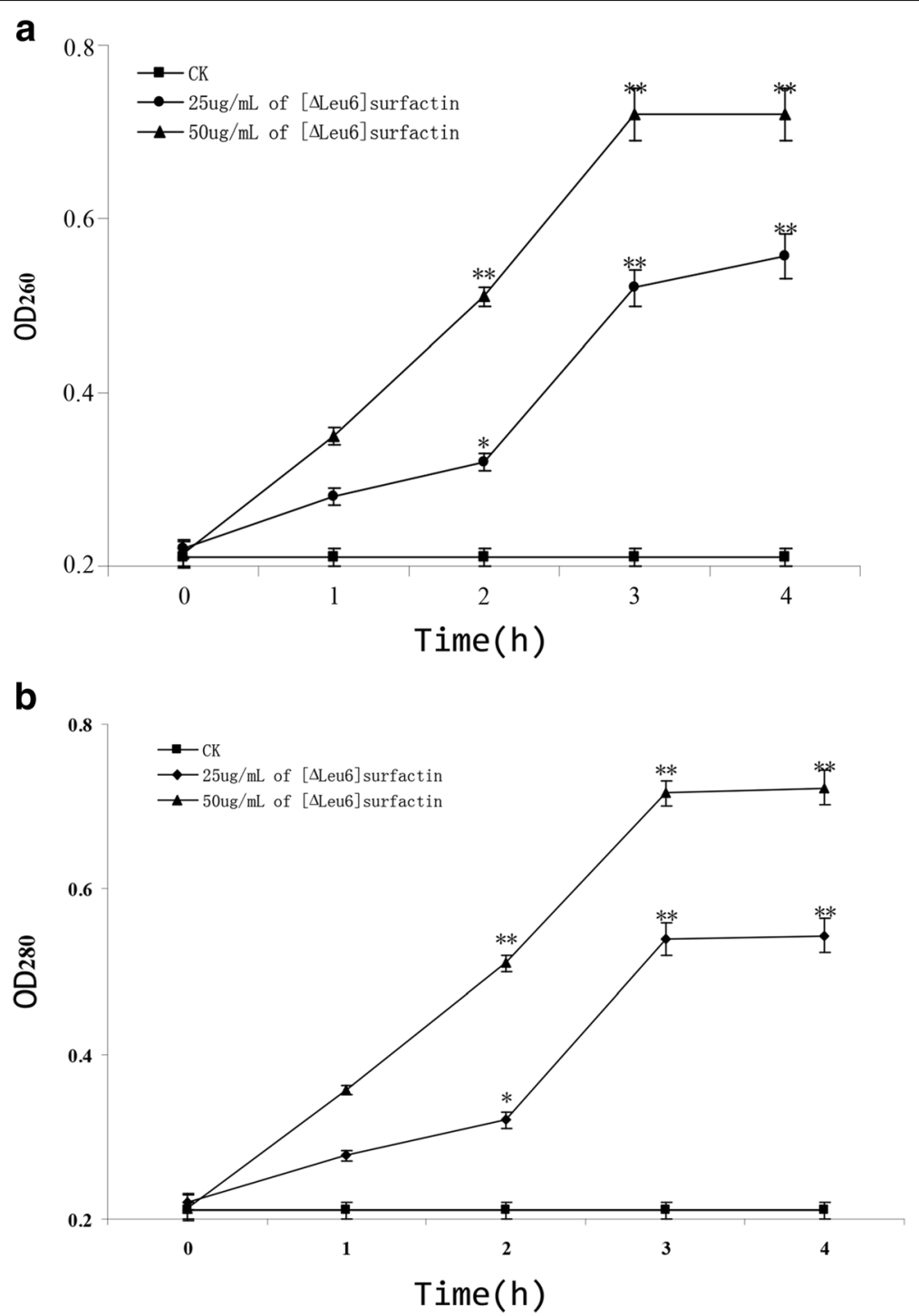

Fig. 8 Divulgation of nucleic acids and proteins of Fusarium moniliforme. CK, samples treated without surfactin. Divulgation of nucleic acids $\left(\mathrm{OD}_{260}\right)$ (a) and proteins $\left(\mathrm{OD}_{280}\right)$ (b) were calculated ( ${ }^{*} P$ value $<0.05$, ${ }^{*} P$ value $\left.<0.01\right)$. The concentration of $\left[\Delta L\right.$ Leu $\left.{ }^{6}\right]$ surfactin was 25 and $50 \mu \mathrm{g} / \mathrm{mL}$. The time of treatment reached 3 hours

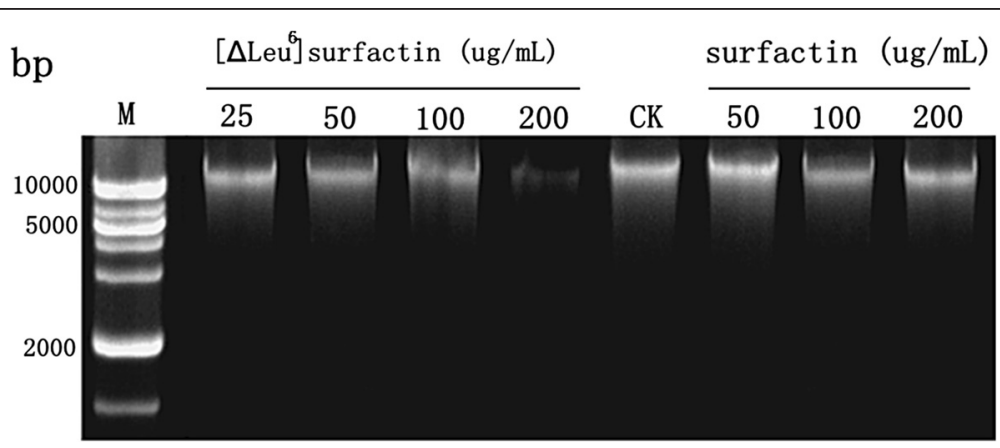

Fig. 9 DNA binding assay by $\left[\Delta \mathrm{Leu}^{6}\right]$ surfactin and surfactin. CK, Fusarium moniliforme DNA was mixed with PBS as control. Fusarium moniliforme DNA was mixed with different amounts of surfactin and $\left[\Delta \mathrm{Leu}^{6}\right]$ surfactin, and then the reaction mixtures after incubating for $1 \mathrm{~h}$ at room temperature were performed to $1 \%$ agarose gel electrophoresis 
epimerization domain has never before been removed. The comS regulation factor is the key factor in forming competent B. subtilis cells. As the comS regulatory factor is contained in the aspartate module, it is difficult to delete this module. Here, it is reported for the first time the complete deletion of this module containing this regulatory factor.

The purification method for novel surfactins draws on experience with a former method for surfactin extraction and purification [35]. For detection of biological activity, the hemolytic activity of $\left[\Delta \mathrm{Asp}^{5}\right]$ surfactin was found to have strengthened antimicrobial activity. For filamentous fungi, no inhibition zones have been discovered. These results revealed that this method for structural transformation of surfactin was feasible and practical.

However, biological activity tests for novel surfactins lacking $D$-leucine showed that the hemolytic activities of $\left[\Delta \mathrm{Leu}^{3}\right]$ surfactin and $\left[\Delta \mathrm{Leu}^{6}\right]$ surfactin were significantly decreased compared with the original surfactin A. $\left[\Delta \mathrm{Leu}^{6}\right]$ surfactin drastically inhibited the growth of $F$. moniliforme hyphae and spores when the $\left[\Delta \mathrm{Leu}^{6}\right]$ surfactin was at $50 \mu \mathrm{g} / \mathrm{mL}$. Therefore, it was evident that $\left[\Delta \mathrm{Leu}^{6}\right]$ surfactin significantly inhibited $F$. moniliforme growth. Surfactin is a well-known lipopeptide biosurfactant with antimicrobial activity, but there is little knowledge regarding surfactin's antifungal activity [36]. Surfactins are not alone in inhibiting filamentous fungi, but C15 surfactin and antifungal drugs have been reported to have a synergistic effect. Surfactins have two polar amino acid residues, such as Glu and Asp, and have been concluded to bind with DNA via hydrogen bonds [37, 38].

SEM and TEM observations indicated that $\left[\Delta \mathrm{Leu}^{6}\right]-$ surfactin obviously affected $F$. moniliforme growth by causing morphological changes in hyphae, suggesting that $\left[\Delta \mathrm{Leu}^{6}\right]$ surfactin markedly contributed to inhibiting fungal growth. DNA binding results indicated that $\left[\Delta \mathrm{Leu}^{6}\right]$ surfactin negatively influenced the maintenance of DNA integrity by binding to F. moniliforme DNA, which might in turn genetically affect DNA function for F. moniliforme growth.

This provides the possibility for a new surfactin with potential for food industry applications. As the original surfactin A has relatively strong hemolytic activity, its use has been restricted in the food industry. The purpose of this study was to develop a novel class of antibacterial lipopeptides from surfactin that possessed reduced cytotoxicity with no significant reduction in antimicrobial activity.

The inhibitory ability of filamentous fungi by three novel surfactins was examined here. Very interestingly, $\left[\Delta \mathrm{Leu}^{3}\right]$ surfactin and $\left[\Delta \mathrm{Leu}^{6}\right]$ surfactin exhibited the ability to inhibit filamentous fungi. These findings extended the known properties of surfactin derivatives as well as related changes in antifungal activity. Further research is needed into the mechanism of this antifungal inhibition.

\section{Conclusion}

In this study, molecular biological tools were successfully employed to transform surfactin synthase and produce three new substances, $\left[\Delta \mathrm{Leu}^{3}\right]$ surfactin, $\left[\Delta \mathrm{Asp}^{5}\right]$ surfactin, and $\left[\Delta \mathrm{Leu}^{6}\right]$ surfactin. Analyses of these substances' biological activity showed that $\left[\Delta \mathrm{Leu}^{3}\right]$ surfactin and $\left[\Delta \mathrm{Leu}^{6}\right]$ surfactin possessed significantly reduced hemolytic activity but with the concurrent appearance of inhibitory ability for filamentous fungi.

\section{Abbreviations}

CK: control check; CFU: colony-forming unit; DNA: deoxyribonucleic acid; ERM: erythromycin; ELISA: enzyme-linked immuno sorbent assay; FTICR-MS: fourier transform ion cyclotron resonance mass spectrometry; HPLC: high performance liquid chromatography; LB: Luria broth; LC: liquid chromatography; MIC: minimal inhibitory concentration; NRPS: non-ribosomal peptide synthetases; OD: optical density; PBS: phosphate buffered saline; PCR: polymerase chain reaction; PDA: potato dextrose agar; PI: propidium iodide; SD: standard deviation; SOE: special operations executive; SrfA: surfactin A; SEM: scanning electron microscope; TEM: transmission electron microscope.

\section{Competing interests}

The authors declare that they have no competing interest.

\section{Authors' contributions}

JJ carried out most of the studies and drafted manuscript. XMB participated in the design, conceived and supervision of this study; and helped to revise the manuscript. LG developed the B. subtilis strain PB2-L1 producing surfactin used in this study. ZXL participated in the supervision and helped for coordination of the study. HXL and CZ participated in the strain selection experiments of the study, FXL and HZZ participated in the surfatin purification experiments of the study. All authors read and approved the final manuscript.

\section{Acknowledgements}

This work was supported by grants from the National Natural Science Foundation of China (grant no. 31271828) and the National Science and Technology Support program (grant no. 2012BAK08807).

Received: 29 March 2015 Accepted: 25 February 2016

Published online: 09 March 2016

\section{References}

1. Gelderblom WCA, Jaskiewicz K, Marasas WFO, Thiel PG, Horak RM, Vleggaar $R$, et al. Fumonisins-Novel Mycotoxins with Cancer-Promoting Activity Produced by Fusarium-Moniliforme. Appl Environ Microbiol. 1988;54(7):1806-11.

2. Sauviat MP, Laurent D, Kohler F, Pellegrin F. Fumonisin, a Toxin from the Fungus Fusarium-Moniliforme Sheld, Blocks Both the Calcium Current and the Mechanical-Activity in Frog Atrial Muscle. Toxicon. 1991;29(8):1025-31.

3. Huang XQ, Wang YF, Cui YH, Hua X. Optimization of Antifungal Effect of Surfactin and Iturin to Penicillium notatum in Syrup of Peach by RSM. Int J Pept Res Ther. 2010;16(2):63-9.

4. Kim SY, Kim JY, Kim SH, Bae HJ, Yi H, Yoon SH, et al. Surfactin from Bacillus subtilis displays anti-proliferative effect via apoptosis induction, cell cycle arrest and survival signaling suppression. Febs Lett. 2007;581(5):865-71.

5. Vollenbroich D, Ozel M, Vater J, Kamp RM, Pauli G. Mechanism of inactivation of enveloped viruses by the biosurfactant surfactin from Bacillus subtilis. Biologicals. 1997;25(3):289-97.

6. Wang Y, Lu ZX, Bie XM, Lv FX. Separation and extraction of antimicrobial lipopeptides produced by Bacillus amyloliquefaciens ES-2 with macroporous resin. Eur Food Res Technol. 2010;231(2):189-96.

7. Seydlova G, Svobodova J. Review of surfactin chemical properties and the potential biomedical applications. Cent Eur J Med. 2008;3(2):123-33.

8. Kleinkauf IW. Energy substitution legislation: Keeping up progress. Brennst-Warme-Kraft. 1996;48(9):3-3. 
9. Mootz HD, Marahiel MA. Biosynthetic systems for nonribosomal peptide antibiotic assembly. Curr Opin Chem Biol. 1997;1(4):543-51.

10. Doekel S, Marahiel MA. Biosynthesis of natural products on modular peptide synthetases. Metab Eng. 2001;3(1):64-77.

11. Bhowmik T, Fernandez L, Steele JL. Gene Replacement in LactobacillusHelveticus. J Bacteriol. 1993;175(19):6341-4.

12. Biswas I, Gruss A, Ehrlich SD, Maguin E. High-Efficiency Gene Inactivation and Replacement System for Gram-Positive Bacteria. J Bacteriol. 1993; 175(11):3628-35

13. Yakimov MM, Giuliano L, Timmis KN, Golyshin PN. Recombinant acylheptapeptide lichenysir: High level of production by Bacillus subtilis cells. J Mol Microb Biotech. 2000;2(2):217-24.

14. Tsuge K, Matsui K, Itaya M. Production of the non-ribosomal peptide plipastatin in Bacillus subtilis regulated by three relevant gene blocks assembled in a single movable DNA segment. J Biotechnol. 2007;129(4):592-603.

15. Landy $M$, Warren $G H$, et al. Bacillomycin; an antibiotic from Bacillus subtilis active against pathogenic fungi. Proc Soc Exp Biol Med. 1948;67(4):539-41.

16. Vollenbroich D, Kluge B, Dsouza C, Zuber P, Vater J. Analysis of a Mutant Amino Acid-Activating Domain of Surfactin Synthetase Bearing a Serine-toAlanine Substitution at the Site of Carboxylthioester Formation. Febs Lett. 1993;325(3):220-4.

17. Chiocchini C, Linne U, Stachelhaus T. In vivo biocombinatorial synthesis of lipopeptides by COM domain-mediated reprogramming of the surfactin biosynthetic complex. Chem Biol. 2006;13(8):899-908.

18. Mootz HD, Kessler N, Linne U, Eppelmann K, Schwarzer D, Marahiel MA. Decreasing the ring size of a cyclic nonribosomal peptide antibiotic by inframe module deletion in the biosynthetic genes. J Am Chem Soc. 2002; 124(37):10980-1.

19. Shatalin KY, Neyfakh AA. Efficient gene inactivation in Bacillus anthracis. Fems Microbiol Lett. 2005;245(2):315-9.

20. Zakataeva NP, Nikitina OV, Gronskiy SV, Romanenkov DV, Livshits VA. A simple method to introduce marker-free genetic modifications into the chromosome of naturally nontransformable Bacillus amyloliquefaciens strains. Appl Microbiol Biot. 2010;85(4):1201-9.

21. Bie XM, Lu ZX, Lu FX, Zeng XX. Screening the main factors affecting extraction of the antimicrobial substance from Bacillus sp fmbJ using the PlackettBurman method. World J Microb Biot. 2005;21(6-7):925-8.

22. Schneider A, Marahiel MA. Genetic evidence for a role of thioesterase domains, integrated in or associated with peptide synthetases, in non-ribosomal peptide biosynthesis in Bacillus subtilis. Arch Microbiol. 1998;169(5):404-10.

23. Kazazic S, Zhang HM, Schaub TM, Emmett MR, Hendrickson CL, Blakney GT, et al. Automated Data Reduction for Hydrogen/Deuterium Exchange Experiments, Enabled by High-Resolution Fourier Transform lon Cyclotron Resonance Mass Spectrometry. J Am Soc Mass Spectr. 2010;21(4):550-8.

24. Nakano MM, Marahiel MA, Zuber P. Identification of a Genetic-Locus Required for Biosynthesis of the Lipopeptide Antibiotic Surfactin in Bacillus-Subtilis. J Bacteriol. 1988;170(12):5662-8.

25. Tagg JR, McGiven AR. Assay system for bacteriocins. Appl Microbiol. 1971;21(5):943.

26. Huang ZH, Hu Y, Shou LF, Song MX. Isolation and partial characterization of cyclic lipopeptide antibiotics produced by Paenibacillus ehimensis B7. BMC Microbiol. 2013;13:87.

27. Sun J, Zhou J, Wang ZH, He WN, Zhang DJ, Tong QQ, et al. Multi-omics based changes in response to cadmium toxicity in Bacillus licheniformis $A$. Rsc Adv. 2015;5(10):7330-9.

28. Assaraf MP, Ginzburg C, Katan J. Weakening and delayed mortality of Fusarium oxysporum by heat treatment: Flow cytometry and growth studies. Phytopathology. 2002;92(9):956-63.

29. Berry CL, Nandi M, Manuel J, Brassinga AKC, Fernando WGD, Loewen PC, et al. Characterization of the Pseudomonas sp DF41 quorum sensing locus and its role in fungal antagonism. Biol Control. 2014;69:82-9.

30. Zhang B, Dong CJ, Shang QM, Han YZ, Li PL. New insights into membraneactive action in plasma membrane of fungal hyphae by the lipopeptide antibiotic bacillomycin L. Bba-Biomembranes. 2013;1828(9):2230-7.

31. Leenders F, Stein TH, Kablitz B, Franke P, Vater J. Rapid typing of Bacillus subtilis strains by their secondary metabolites using matrix-assisted laser desorption ionization mass spectrometry of intact cells. Rapid Commun Mass Sp. 1999;13(10):943-9.

32. Stachelhaus T, Schneider A, Marahiel MA. Rational Design of Peptide Antibiotics by Targeted Replacement of Bacterial and Fungal Domains. Science. 1995;269(5220):69-72.
33. Symmank H, Franke P, Saenger W, Bernhard F. Modification of biologically active peptides: production of a novel lipohexapeptide after engineering of Bacillus subtilis surfactin synthetase. Protein Eng. 2002;15(11):913-21.

34. Schneider A, Stachelhaus T, Marahiel MA. Targeted alteration of the substrate specificity of peptide synthetases by rational module swapping. Mol Gen Genet. 1998;257(3):308-18.

35. Desai JD, Banat IM. Microbial production of surfactants and their commercial potential. Microbiol Mol Biol R. 1997;61(1):47.

36. Liu XY, Ren BA, Gao H, Liu M, Dai HQ, Song FH, et al. Optimization for the Production of Surfactin with a New Synergistic Antifungal Activity. Plos One. 2012;7(5):e34430

37. Ahmad S, Gromiha MM, Sarai A. Analysis and prediction of DNA-binding proteins and their binding residues based on composition, sequence and structural information. Bioinformatics. 2004;20(4):477-86.

38. Luscombe NM, Thornton JM. Protein-DNA interactions: amino acid conservation and the effects of mutations on binding specificity. J Mol Biol. 2002; 320(5):991-1009.

\section{Submit your next manuscript to BioMed Central and we will help you at every step:}

- We accept pre-submission inquiries

- Our selector tool helps you to find the most relevant journal

- We provide round the clock customer support

- Convenient online submission

- Thorough peer review

- Inclusion in PubMed and all major indexing services

- Maximum visibility for your research

Submit your manuscript at www.biomedcentral.com/submit
) Biomed Central 